\title{
HERBIVOROUS INSECTS DIVERSITY AT MISCANTHUS $\times$ GIGANTEUS IN UKRAINE
}

\section{TATYANA STEFANOVSKA ${ }^{1 *}$, VALENTINA PIDLISNYUK², EDWIN LEWIS ${ }^{3}$, ANATOLIY GORBATENKO ${ }^{1}$}

\author{
${ }^{1}$ National University of Life and Environmental Sciences of Ukraine, Ukraine \\ ${ }^{2}$ Jan Evangelista Purkyne University in Usti nad Labem, Czech Republic \\ ${ }^{3}$ University of California in Davis, USA
} STEFANOVSKA, T. - PIDLISNYUK, V. - LEWIS, E. - GORBATENKO, A.: Herbivorous insects diversity at
Miscanthus $\times$ giganteus in Ukraine. Agriculture (Pol'nohospodárstvo), vol. 63, 2017, no. 1, p. 23-32.

\begin{abstract}
Miscanthus $\times$ giganteus is considered as a perspective energy crop for biomass production in Ukraine where its commercial production has been observed. The herbivorous pest may pose a risk of yield reduction when an energy crop is growing on monoculture. The herbivorous diversity, species composition and potential damage associated with growing M. $\times$ giganteus were studied on seven experimental sites at three locations in Ukraine. The different life stages of herbivorous insects from seven orders representing thirteen families were found on $M$. $\times$ giganteus during the herbivorous survey and most of the insects had a pest status. Research indicated that crop was an alternate host for key cereal pest the Hessian fly Mayetiola destructor (Say) (Diptera: Cecidomyiidae). A comparative analysis of the biodiversity of herbivorous insects across research locations was done using statistical analysis. It was found that site location played a significant role in the level of biodiversity and an increase in the insect's herbivores diversity was associated with the type of researched lands. The massive scale commercial use of $M . \times$ giganteus should take into account a responsible consideration of the benefits and risks associated with that crop in order to protect agroecosystems.
\end{abstract}

Key words: survey of herbivorous insects, pest, Hessian fly, statistical method

M. $\times$ giganteus is a sterile hybrid of two species: M. sinensis and M. sacchariflorus, and is native to Southern Asia (Hodkinson et al. 2002). Plant belongs to C-4 photosynthetic pathway type and has a capacity for effective and substantial biomass production (Zub \& Brancourt 2010; Agostini et al. 2015). The biological feature of that crop is its ability to grow at the contaminated and abandoned sites, which makes it appropriate for phytotechnologies (Otepka et al. 2011; Pidlisnyuk et al. 2014; Nsanganwimana et al. 2016). The $M$. $\times$ giganteus potential for biofuel production has been extensively researched in Europe (Lewandowski et al. 2003; Gauder et al.2012), including Slovakia (Porvaz et al. 2012; Jurekova et al. 2013; Gubisova et al. 2016) and Czech Republic (Vaprova \& Knapek 2010; Strasil 2016). M. × giganteus perennial rhizomatous grass's feature makes its establishment and reproduction very costly. Recently, significant progress was achieved in the development of $M . \times$ giganteus hybrid seed; the planting of this hybrid seed leads to a more economically feasible crop production than using the rhizomes (Clifton-Brown et al. 2017). Nowadays,

Tatyana Stefanovska, PhD., Associate Professor (*Corresponding author), Department of Entomology, National University of life and Environmental Sciences of Ukraine, 13 Heroyiv Oborony, Kyiv 03041, Ukraine. E-mail: tstefanovska@nubip. edu.ua

Valentina Pidlisnyuk, DSc., Professor, Department of Technical Sciences, Jan Evangelista Purkyne University, Kralova vysina 7, 40096 Usti nad Labem, Czech Republic. E-mail: pidlisnyuk@gmail.com

Edwin Lewis, PhD., Professor, Department of Entomology, University of Califonia, California, 479 Hutchison Hall, One Shields Ave, Davis CA 95616, USA. E-mail: elewis@ucdavis.edu

Anatoliy Gorbatenko, PhD., Associate Professor, Department of Ecology, National University of Life and Environmental Sciences of Ukraine, 13, Heroyiv Oborony, Kyiv 03041, Ukraine. E-mail: a.gorbatenko@nubip.edu.ua 
the crop is used commercially for heating and generating electricity in several EU countries. In the US, the crop has been proposed for commercial production in Midwest and Northern States, particularly in locations where the precipitation is not a limiting factor. The number of growing sites has been expended in the US rapidly; however, the commercial production has not been well established yet (Heaton et al. 2008).

Currently, no pests of economic importance are found in M. × giganteus in Europe or the US. The European experience with $M . \times$ giganteus planting showed that the crop has low level of risk from pest damage. However, taking in consideration a hybrid nature of the crop, any pest associated issues that do arise may cause a serious problem (Thomson \& Hoffmann 2010). Only few pests have been reported that directly damage the crop (Semere \& Slater 2007). The survey of invertebrates of $M . \times$ giganteus in the United Kingdom indicated that there were "no major pests found" (Hugget et al. 1999). Results of the twoyear research in Germany showed the damage of crop by two-spotted spider mite Tetranychus urticae. Koch Gottwald and Adam (1998), Semere and Slater (2007) recorded that aphids were the dominated Homoptera group found on field trials of Miscanthus. This finding may raise the issue of how aphids indirectly affect the crop by transmitting viruses. Several researches indicated that the crop, that may contribute to the distribution of viruses, were transmitted by aphids. It was observed that corn leaf aphid Rhopalosiphum maidis (Fitch) may colonize Miscanthus and lay eggs on the established plants. The laboratory studies showed that aphid feeding on $M . \times$ giganteus transmitted viruses: Barley Yellow Dwarf virus (Christian et al. 1994; Hugg et al. 1999) and the sorghum mosaic virus (Grisham et al. 2012).

The results of recent studies in the Northern France, where the cultivation of $M . \times$ gigantheus started in the early 2000 s, gave a new argument regarding the concern on increasing the risk of speeding phytoviruses by aphids and Miscanthus acting as reservoir for aphids' pests from neighbouring food crops. Coulette et al. (2013) showed that M. sacchariflorus (parental species for M. $\times$ giganteus) did not appear as an appropriate host for the three aphid species Aphis fabae Scop, Myzus persicae (Sulzer) and Rhopalosiphum padi L. Ameline et al. (2015) reported that the host suitability for the four major aphis depends on the degree of specialization to Poaceae and appeared as moderate for specialist Rhopalosiphum padi L., low for polyphagous Aphis fabae (Scop) and Myzus persicae (Sulzer) and as very low for Brassicae specialist Brevicoryne brassicae L. In controversy, this study illustrated that the cultivation of Miscanthus in large scale might not always aggravate the problem of creating reservoir aphids from adjusting food crops; it could be assumed that $M . \times$ giganteus acted as a barrier crop helping to reduce the risk of transmission and spread of phytoviruses.

The recording of direct increasing damage by several insects in the US may be evidence to suggest that $M . \times$ giganteus has pests; its effect on biomass is still unknown and its severity will depend on the scale and the time of plant's growth. The fact that all insects reported to feed on $M . \times$ giganteus in the US are pests of corn, sugarcane or sorghum, raises concerns that the production of that crop in the large scale will increase pest numbers in existing food crops. It can be well illustrated by the relationship between $M . \times$ giganteus and corn (Bradshaw et al. 2010). M. × giganteus appeared as a host to the yellow sugarcane aphid and may cause damage in young stands in the field condition. The potential of Sipha flava (Forbes) to damage M. $\times$ giganteus in case of a large-scale cultivation was confirmed in the laboratory research (Pallipparambil et al. 2014), when the crop served as a host plant for corn rootworm determined as dangerous maize pest (Spencer \& Raghu 2009). It was indicated (Gloyna et al. 2011) that the larvae of Western corn rootworm, of Diabrotica virgifera virgifera (Le Conte) originating from a Central and South Eastern European population, could be developed at $M . \times$ giganteus. Armyworm and stem borer, which were host of corn and sorghum species, were able to feed on the crop as well.

Prasifka et al. (2009) showed that M. × giganteus along with switch grass was a host of fall armyworm Spodoptera frugiperda (J. E. Smith) determined as a pest of corn was observed in the 
infesting plots. Laboratory test showed that $S$. frugiperda larva preferred corn leaves over Miscanthus ones. The pest was able to complete the development on Miscanthus and switchgrass at the green house conditions; however, it did not survive well during the field experiment. As it was reported by Prasifka et al. (2012), the stem-boring caterpillars: Elasmopalpus lignosellus (Zeller) (Pyralidae), Diatraea saccharalis (F.) (Pyralidae), and Mexican Rice Borer Eoreuma loftini (Dyar) (Crambidae) might cause $M . \times$ giganteus biomass reduction, and a long-term investment in breeding for host plant resistance might be requested.

Since 2004 M. × giganteus was under evaluation for commercial production in eight regions of Ukraine (Kvak 2013), an emerging commercial production has been currently observed and the area under cultivation is about 1,500 ha with expectation of significant extending in the nearest future (Pidlisnyuk \& Stefanovska 2016). This trend is due to the increasing biofuel demands, energy security concern and political desire to increase the share of bioenergy in the country's energy balance (Geletukha et al.2015). The fact is illustrated in Figure 1.

Growing interest and commercialization of $M . \times$ giganteus production in Ukraine will lead to land use changes and possible cultivation of the crop in monoculture. The land use change is a significant contributor of biodiversity changing (Whittaker et al. 2001). Some previous studies indicated a positive effect of $M . \times$ giganteus, growing to biodiversity service (Semere 2007; Gauder et al. 2012; Dauber et al. 2015), when the crop hosted several arthropods, particular predatory ground beetles and parasitoids - natural enemies of important agricultural pests. Stanley and Stout (2013) indicated that $M . \times$ giganteus supported higher abundance and diversity of pollinators and hymenopteran wasps comprised to traditional food crops. Another study concerned about the possible negative impact of $M . \times$ giganteus growing to the state of biodiversity (Stefanovska et al. 2011).

There are several factors that determine species diversity, particular spatial arrangement of habitat elements and the spatial-temporal heterogeneity of the landscape (Schluter \& Ricklefs 1994; Lewinsohn et al. 2005; Rocca \& Greko 2011). In comparison to Western Europe and the US, very lim- ited data exists on that topic while growing $M . \times$ giganteus in Eastern Europe, including Ukraine. The purpose of this study was to do a survey of herbivorous insects in field conditions at different regions of Ukraine and to analyse the abundance, richness and biodiversity of common insect herbivores while growing $M . \times$ giganteus in seven sites at three different locations: Vinnytsia, Zhytomyr and Kyiv regions.

\section{MATERIAL AND METHODS}

The selected locations represented the areas which have high potential for biofuelcrops' production (Geletukha et al. 2015). A total of seven established plots of $M . \times$ giganteus varying in time of cultivation were chosen for herbivorous sampling. Plot sizes varied from $25 \mathrm{~m}^{2}$ to $100 \mathrm{~m}^{2}$. Some characteristics of the plots are presented at Table 1. For all the plots, M. $\times$ giganteus was planted manually in the soil depth of $0.05-0.1 \mathrm{~m}$ with spacing of $0.70 \mathrm{~m} \times 0.70 \mathrm{~m}$, which was equal to 20 pieces of plant per $\mathrm{m}^{2}$; planting was done in the period of end of April to middle of May, depending of the annual weather conditions that determined the features of the vegetation season. The way of planting Miscanthus was same for each year of planting. The insect sampling was conducted at 2010 and 2011. Visual observation and sampling was conducted at five subplots randomly located within the planting at a minimum of $10 \mathrm{~m}$ from the plot edge to reduce edge effects. Above ground insect samples were collected every four weeks during the growing season using both active and passive sampling methods (Binns et al. 2000). Active sampling, through sweep net and stem was performed prior to the passive sampling methods. Stem counts were geared towards sedentary aphids. Sweep net sampling was a direct sampling method that would collect insects on the foliage of the plant. Twenty sweeps were taken down off the alternate crop rows and the specimens were collected and preserved in $90 \%$ ethanol solution until identification. In passive samples, Pitfall traps (Prasifka et al. 2007) were used for the collection of ground dwelling insects and sticky cards were used for the collection of 
small arboreal insects. Pitfall traps and yellow sticky cards were set up in a grid pattern with $1 \mathrm{~m}$ spacing. The traps were replaced weekly from the beginning of June till the end of July. All the traps were transferred to the laboratory for further insects' identification. For the sampling of Elateridae and Scarabaeidae species, a method of spring soil excavation was implemented. At each plot, the holes $0.50 \times 0.59 \mathrm{~m}$ at depth $0.50 \mathrm{~m}$ were dug. The excavated soil samples were sieved and extensively screened for larvae at all stages of wireworms, grubs, mole crickets and cutworms, which were counted further.

The insect presented in the traps was identified till higher taxon and the selected herbivorous trophic groups were identified till species or at least till genera.

The data obtained from 2010 and 2011 years of insect sampling data are presented together in the same diagrams.

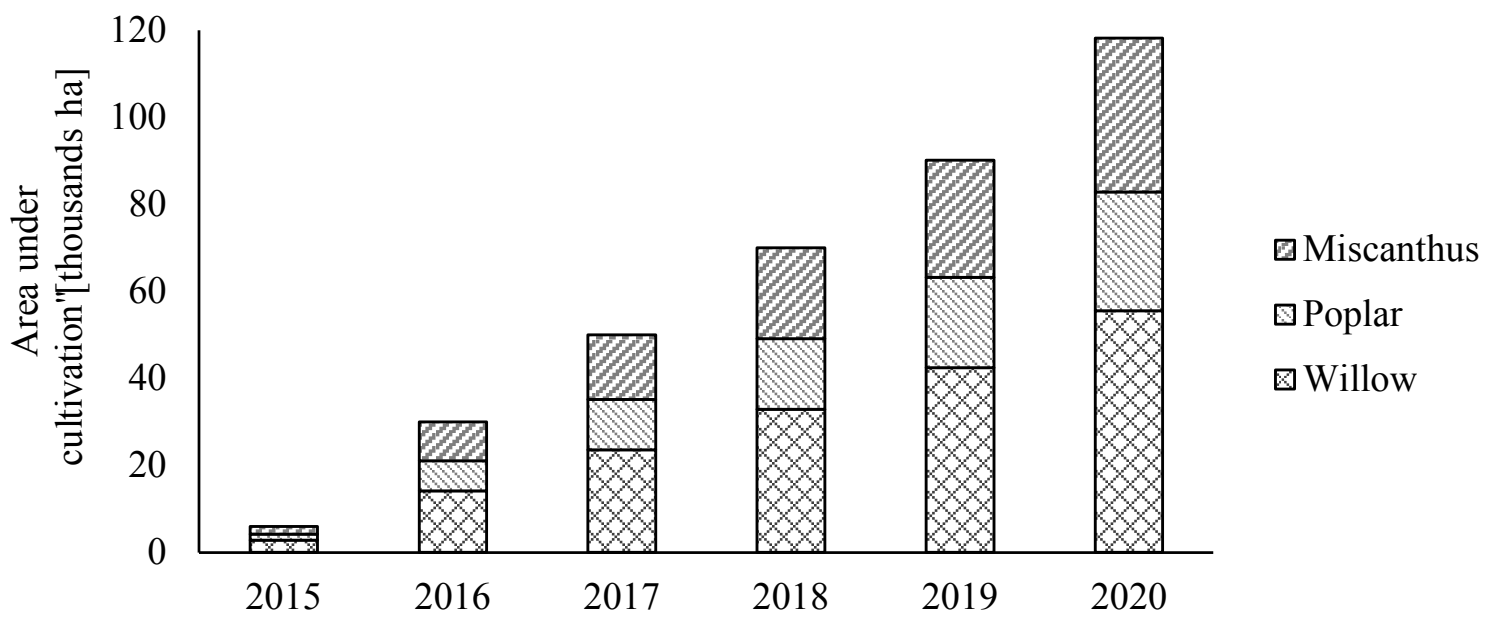

Figure 1. Prediction of energy crops area cultivation (Geletukha et al. 2015)

T

Characteristics of the research sites

\begin{tabular}{|c|c|c|c|c|c|}
\hline Site location & Site and plot number & Location (GPS) & $\begin{array}{l}\text { Year } \\
\text { of the } \\
\text { study }\end{array}$ & $\begin{array}{c}\text { Year } \\
\text { of the } \\
\text { growing }\end{array}$ & Type of the soil \\
\hline \multirow{2}{*}{ Zhytomyr } & site 1, plot 1 & $\begin{array}{l}50.252385 \\
28.70011\end{array}$ & $\begin{array}{l}2010 \\
2011\end{array}$ & $\begin{array}{l}3 \\
4\end{array}$ & \multirow{2}{*}{ Podzolic gleyed } \\
\hline & site 1 , plot 2 & $\begin{array}{l}50.252385 \\
28.70011\end{array}$ & $\begin{array}{l}2010 \\
2011\end{array}$ & $\begin{array}{l}6 \\
7\end{array}$ & \\
\hline \multirow{2}{*}{ Vinnytsia } & & $\begin{array}{l}48.997958 \\
27.462125\end{array}$ & $\begin{array}{l}2010 \\
2011\end{array}$ & $\begin{array}{l}1 \\
2\end{array}$ & \multirow{2}{*}{$\begin{array}{l}\text { Flooded grey } \\
\text { podzolic soil }\end{array}$} \\
\hline & site 1 , plot 2 & $\begin{array}{l}48.997958 \\
27.462125 \\
\end{array}$ & $\begin{array}{l}2010 \\
2011\end{array}$ & $\begin{array}{l}3 \\
4\end{array}$ & \\
\hline \multirow{3}{*}{ Kyiv } & site 1, plot 1 & $\begin{array}{l}50.42945 \\
30.494808\end{array}$ & $\begin{array}{l}2010 \\
2011\end{array}$ & $\begin{array}{l}1 \\
2\end{array}$ & \multirow{3}{*}{ Dark grey soil } \\
\hline & site 1 , plot 2 & $\begin{array}{l}50.42945 \\
30.494808\end{array}$ & $\begin{array}{l}2010 \\
2011\end{array}$ & $\begin{array}{l}3 \\
4\end{array}$ & \\
\hline & site 2 , plot 1 & $\begin{array}{l}50.415087 \\
30.55705\end{array}$ & $\begin{array}{l}2010 \\
2011\end{array}$ & $\begin{array}{l}1 \\
2\end{array}$ & \\
\hline
\end{tabular}


In order to assess the insect biodiversity, the Shannon index (Shannon 1948) was measured.

$$
\mathrm{H}=-\Sigma p_{i} \log _{2}\left(p_{i}\right)
$$

where:

$\mathrm{P}_{\mathrm{i}}=\mathrm{n}_{\mathrm{i}} / \mathrm{N}$

$\left(n_{i}\right)$ - sharing of the specie; $(N)$ - total number of individuals

In order to determine the diversity of herbivorous taxa, we referred to the different research sites and to find the maximum entropy for each taxa of herbivores, the Hartley approach was used (2), in which $\mathrm{N}$ - number of taxa, as for the case:

$$
\mathrm{H}_{\max }=\log _{2} N(2)
$$

The Pielow's evenness index (3) was calculated by dividing the Shannon index ratio (1) by its maximum value (2), in order to align data from one site with other sites:

$$
\mathrm{H}^{\prime}=\frac{H}{\mathrm{H}_{\max }}(3)
$$

Parametric statistical method, student's t-test and ANOVA were used to compare herbivore diversity across the sites in 2010-2011.

\section{RESULTS AND DISCUSSION}

Results of the survey of herbivorous insects provided at different sites where $M . \times$ giganteus grown are shown at Figure 2. The analysis of outcomes shows the different life stages of insects from seven orders and families observed during the 2010-2011 growing seasons across the sites. Specifically, among the recorded herbivorous generalists and highly specialists for Poaceae family pests were found for all the sites. The soil dwelling polyphagous insect (Gryllotalpa gryllotalpa L., Melolontha melolontha L. and Agrotis segetum $\mathrm{S}$.) were recorded at three sites located in Vinnytsia and Kyiv in the first year of growing M. × giganteus; no significant plant's injury by insects was observed with one exception of the Hessian fly. Its larvae and pupae were observed inside the stems of the plant in one plot located in Zhytomyr region. It was evident that Aphidi- idae (Homoptera) and Thripidae (Thysanoptera) families were dominated at three locations. The Rhopalosiphum padii L. was the most widely represented species for all the researched sites and the Herbivorous trips were found in three sites. That fact is in correlation with results reported by Hurej and Twardowski (2009), who observed this group of sub sucking insects at M. × giganteus plots in Poland during the first years of cultivation.

Overall, 50 species of herbivorous trips were registered at the agricultural landscapes in Ukraine. In this study, the high population trips' density was observed in three locations (Figure $3)$. That trend can be due to the weather conditions in the research years, which were very favourable for the trips' development because of warm and dry summer. Leaf hopper, Psammotettix striatus L. were additionally recorded in the site located at Vinnytsia region, which was more southern in geographical location in comparison with other sites.

Shannon and Pielow's evenness indexes were used for the comparison of biodiversity of herbivorous insects across research locations. Results of the calculation of average data in 2010-2011 are presented at Figure 4, Table 2 and Table 3. It was hypothesized that the factor of location influenced the biodiversity of herbivorous insects. Following the performing the share of influence of considering and not considering that factors location was determined. The results showed that the impact of the factor 'location 'was 51\%. Since $F$ Theoretical $>F$ Critical (Table 2), the null hypothesis might be rejected, that is, the site location played a significant role in the level of biodiversity. Results also showed that the increase in the diversity of insect herbivores was associated with the type of observed lands. Thus, Vinnytsia site located in more agricultural setting (with many crops types) illustrated a significantly higher level of species diversity in comparison with other locations in Zhytomyr and Kyiv regions, which showed few types of crops.

Analysis of previous research results indicated that $M . \times$ giganteus did not have many herbivorous pests, which in turn confirmed the statement that $M . \times$ giganteus cultivated fields could be 
served as a refuge for insect herbivores. Hence, the more the fields with various agricultural crops surround Miscanthus field, the more likely it is that the pests from those fields will move to the Miscanthus field. It can be concluded that the introduction of $M . \times$ giganteus in crop rotation may help to improve the environmental sustainability of the agricultural landscapes through the conservation of natural species and territory, and the plant's growth may work as ecological corri- dors. Profound research is needed for studying the interaction of $M . \times$ giganteus with other trophic groups of insects, particularly entomophagous and soil micro and mezofauma.

The importance of documenting trips, aphids and leafhoppers population data is three-fold. First, the pests may have a direct impact on crop production and profitability. Second, many of these insects are also associated with current crops, such as wheat, and may build up large populations

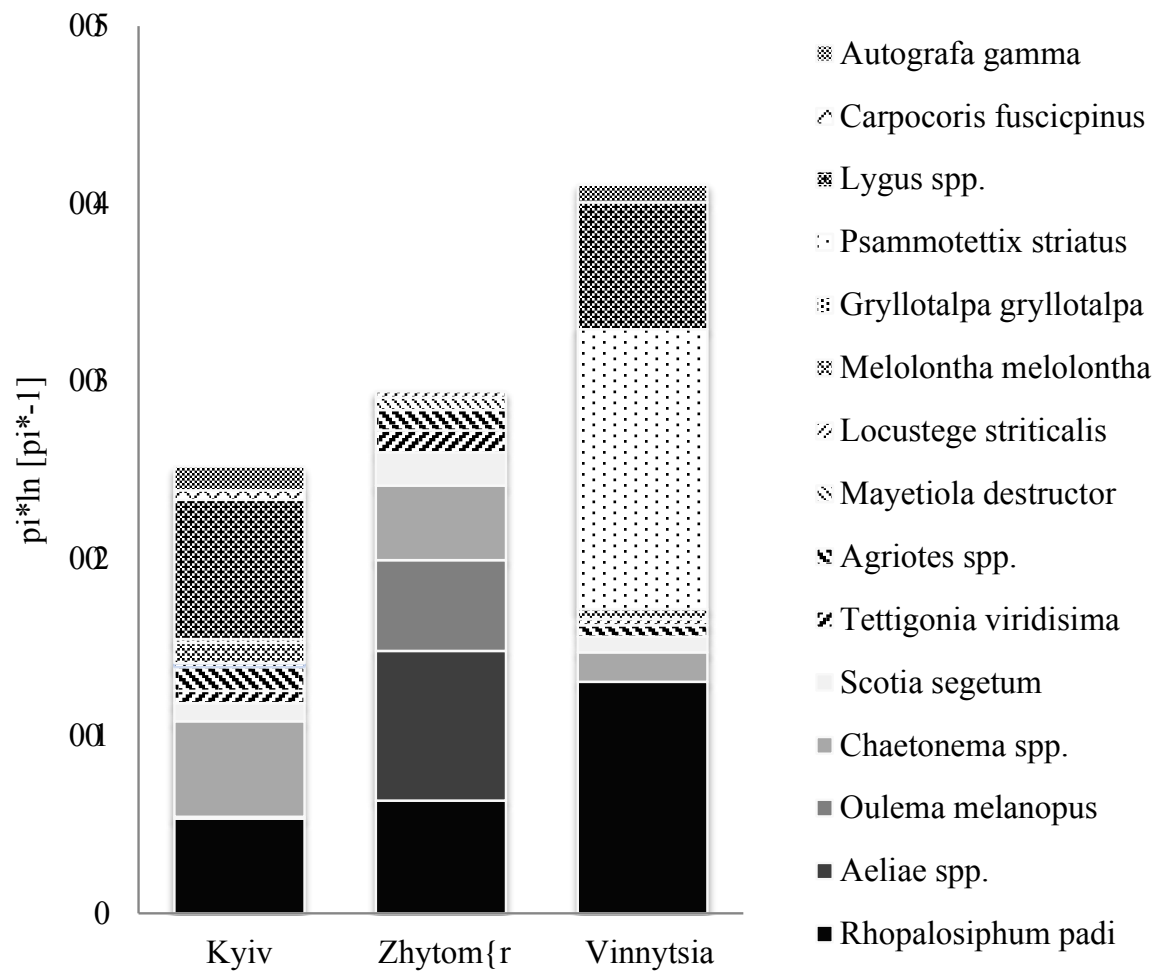

Figure 2. Variation of insect species and genera on Miscanthus $\times$ giganteus at three research locations in 2010-2011 growing seasons

$\mathrm{T}$ a

Shannon index in sites

\begin{tabular}{|c|c|c|c|c|}
\hline Site & Zhytomyr & Vinnytsia & Kyiv, site 1 & Kyiv, site 2 \\
\hline 1 & 0.46 & 0.59 & 0.42 & 0.46 \\
2 & 0.46 & 0.67 & 0.44 & 0.58 \\
3 & 0.76 & 0.78 & 0.47 & 0.32 \\
4 & 0.33 & 0.93 & 0.52 & $\mathrm{n} / \mathrm{d}$ \\
$\mathrm{M}$ & 0.50 & 0.74 & 0.46 & 0.46 \\
$\pm \mathrm{m}$ & 0.09 & 0.07 & 0.02 & 0.08 \\
\hline
\end{tabular}

$\mathrm{M}$ - mean; SE - Standard error 

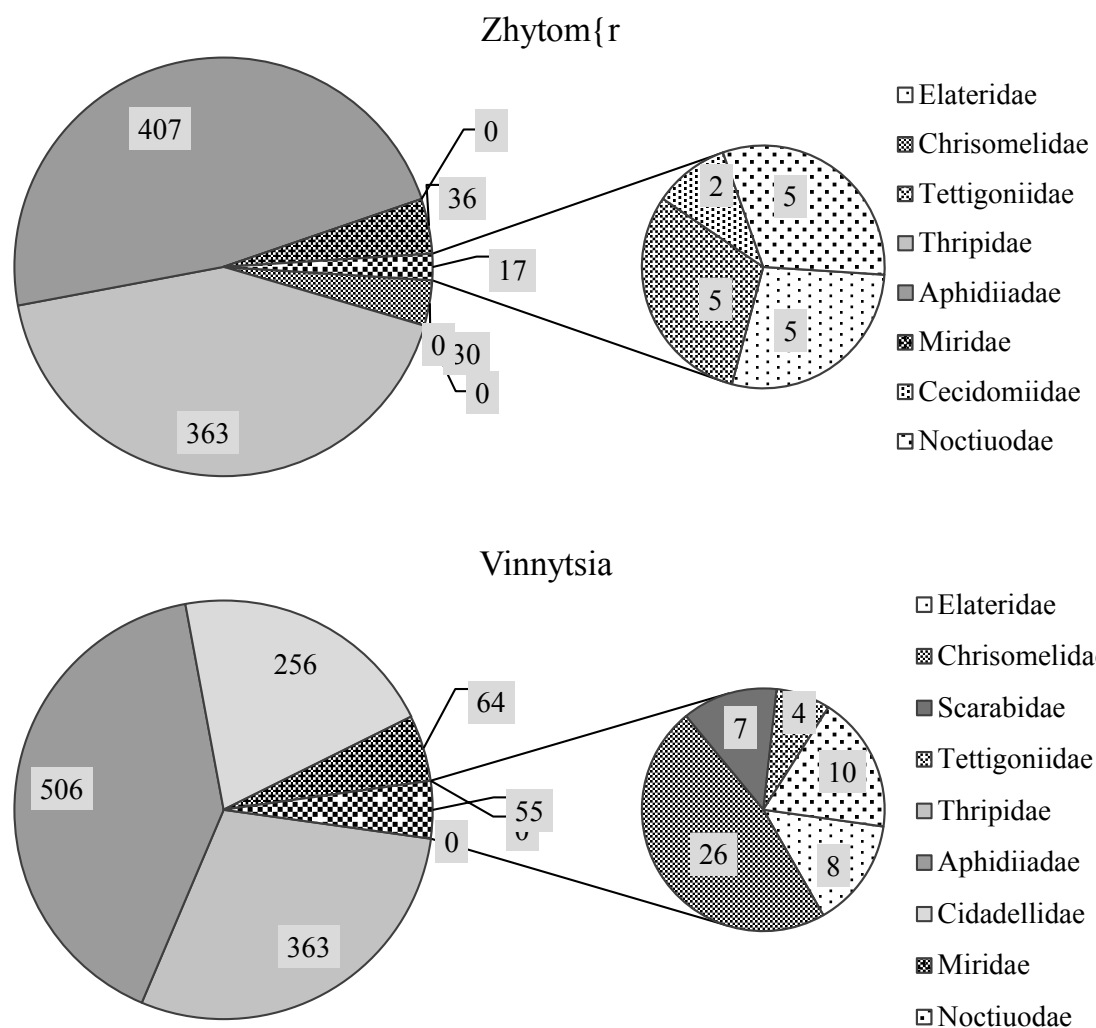

$๑$ Elateridae

Chrisomelidae

$\square$ Scarabidae

图 Tettigoniidae

$\square$ Thripidae

$\square$ Aphidiiadae

$\square$ Cidadellidae

중 Miridae

$\square$ Noctiuodae

Kyiv $\square 1$

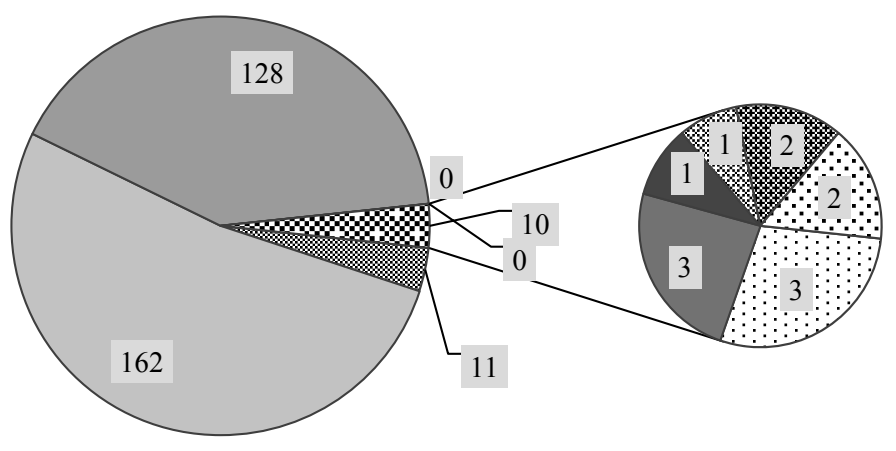

๑lateridae

㘣Chrisomelidae

$\square$ Scarabidae

- Grylloitalpidae

Tettigoniidae

$\square$ Thripidae

$\square$ Aphidiiadae

* Miridae

$\checkmark$ Noctiuodae

Kyiv 2

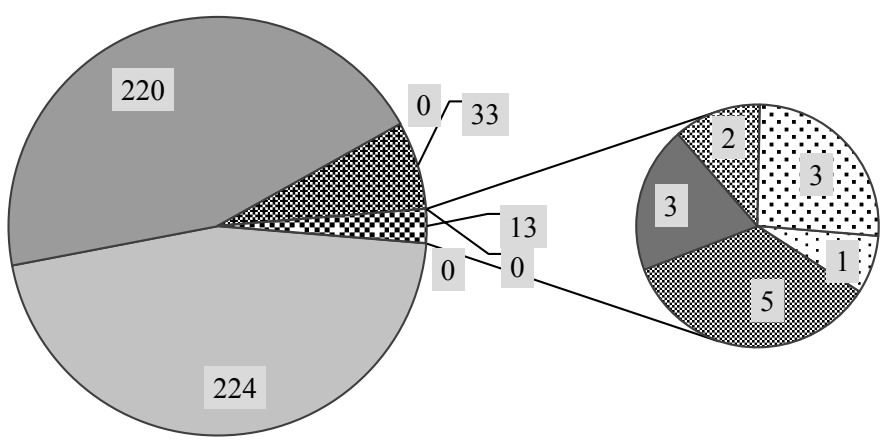

घElateridae

. Chrisomelidae

$\square$ Scarabidae

-Grylloitalpidae

⿴囗十 Tettigoniidae

$\square$ Thripidae

$\square$ Aphidiiadae

口Cidadellidae

圈 Miridae

$\exists$ Cecidomiidae

口Noctiuodae

Figure 3. Number of herbivorous individuals in different stages at three locations in 2010-2011 growing seasons 
that could then migrate into production fields. Third, two of the most commonly found insects: the aphid Rhopalosiphum padi L. and the leafhopper Psammotettix striatus L. are both vectors of wheat diseases; thus, $M$. $\times$ giganteus could potentially serve as harbourage for vectors and disease.

The survey found that $M . \times$ giganteus was an alternate host for a key cereal pest the Hessian fly Mayetiola destructor (Say) (Diptera: Cecidomyiidae). Since Hessian fly, along with other species from the families Chrolopidae and Antomyidae, is a destructive pest for several cereal crops, there is a potential risk that the insect may reduce the yield of Miscanthus and damage adjacent food crops. Because intercropping is a com- mon practice in Ukraine wheat, barley and oats may be potentially affected by this insect as well. It highlights that the current studies of Hessian fly colonization of Miscanthus plantings should be prolonged for the evaluation of potential risks to other crops and wild species sharing the agricultural landscape.

The fact that $M . \times$ giganteus appeared as a good host for the Western root corn beetle brings a new challenge for the commercial growing of that plant, which may increase the risk of further distribution of Diabrotica virgifera virgifera (Le Conte) throughout the country (Andreyanova \& Sikura 2010).

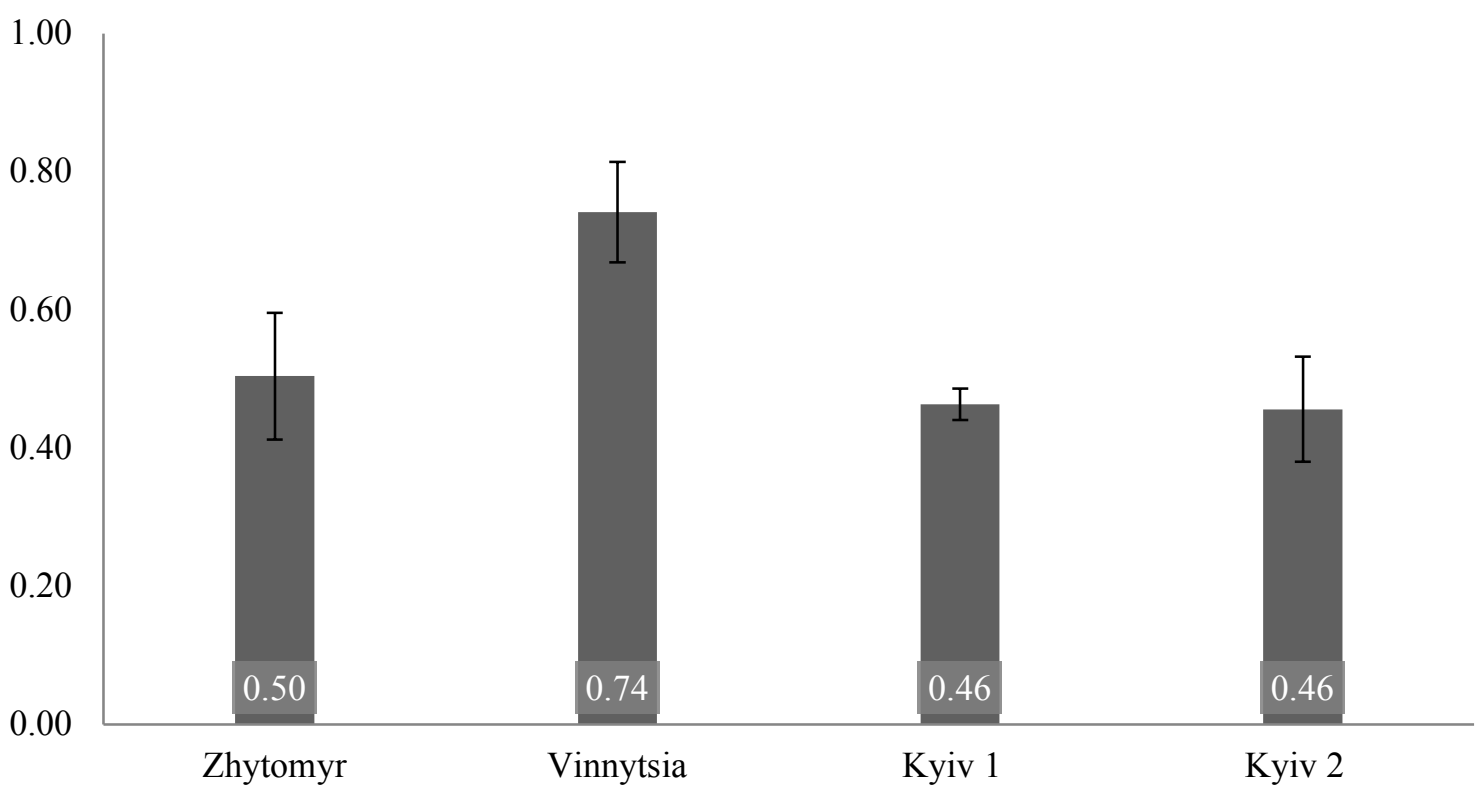

Figure 4. Pielow's evenness index (average value) for three location in 2010-2011 growing seasons

$$
\mathrm{T} \text { a }
$$

Variations between groups as for ANOVA

\begin{tabular}{|l|c|c|c|c|c|c|}
\hline Variation & $\mathrm{SS}$ & $\mathrm{df}$ & $\mathrm{MS}$ & $F c$ & $P$-value & $F d$ \\
\hline Between groups & 0.211 & 3 & 0.07 & 3.78 & 0.05 & 3.59 \\
Inside groups & 0.205 & 11 & 0.02 & & & \\
All together & 0.416 & 15 & & & & \\
\hline
\end{tabular}

$F c-F$ calculated; $F d-F$ distribution 


\section{CONCLUSIONS}

The study indicates that intensive involvement of perennial grass $M . \times$ giganteus into the agricultural landscape in Ukraine, dominated by cereal crops from the same family Poaceae (wheat, corn, rye), stimulates numerous indirect interactions between that crop and small grain cereals and can pose a risk to agricultural landscapes as all. The conversion of marginal and abandoned lands, where the growing of $M . \times$ giganteus is profitable into monoculture production areas can bring new environmental challenge. Hence, the massive scale commercial use of $M . \times$ giganteus should take into account a responsible consideration of the benefits and risks associated with that crop, in order to protect the agricultural ecosystems that supply food, feed and increasingly, the fuel.

Acknowledgements. The research was supported by CRDF UKB1-2959-KV-08 and NATO SPS MYP\#G4687.

\section{REFERENCES}

AMELINE, A. - KERDELLANT, E. - ROMBAUT, A. CHESNAIS, Q. - DUBOIS, F. - LASUE, P. - COULETTE, Q. - RAMBAUT, C. - COUTY, A. 2015. Status of the bioenergy crop miscanthus as a potential reservoir for aphid pests. In Industrial crops and products, vol. 74, pp. 103110.

ANDREYANOVA, N.I. - SIKURA, O.A. 2010. Risk of reduction and distribution of Diabrotica virgifera Le conte in pest free regions of Ukraine. In Nauloviy Visnuk Uzgorodsogo Universitetu, Biologia seria, vol. 29, pp. 167-169 (in Ukrainian).

BINNS, M.R. - NYROP, J.P. - VAN DER, W. 2000. Sampling and monitoring in crop protection: the theoretical basis for developing practical decision guides. Wallingford, Oxon, UK: CABI Publ., 314 p. ISBN0851993478. DOI: 10.1046/j.1439-0329.2001.0257c.x

BRADSHAW, J.D. - PRASIFKA, J.R. - STEFFEY, K.L. GRAY, M.E. 2010. First report of field populations of two potential aphid pests of the bioenergy crop Miscanthus $x$ giganteus. In Florida Entomologist, vol. 93, no. 1, pp.135137. DOI: $10.1653 / 024.093 .0123$

CHRISTIAN, D.G. - LAMPTEY, J.N.L. - FORDE, S.M.D. PLUMB, R.T. 1994. First report of barley yellow draft liteovarus on Miscanthus in the United Kingdom. In European Journal of Plant Pathology, vol. 100, pp.167-170. DOI: 10.1007/BF01876249

CLIFTON-BROWN, J. - HASTINGS, A. - MOS, M. - MCCALMONT, J.P. - ASHMAN, C. - CARROLL, D.A. CERAZY, J. - CHIANG, Y.C. - COSENTINO, S. - CRACROFT-ELEY, W. - SCURLOCK, J. - DONNISO, I.S. - GLOVER. C. - GOŁAB, I. - GREEF, J.M. - GWYN,
J. - HARDING, G. - HYES,C. - HELIOS, W. - HSU. T-W. - HUANG, L.S. - JEZOWSKI, S. - KIM, D-S. - KIESEL, A. - KOTECKI, A. - KRZYZAK, J. - LEWANDOWSKI, I. - LIM, S.H. - LIU, J.- LOOSELY, M. - MEYER, H. MURPHY-BOKERN, D. - NELSON, W. - POGRZEBA, M. - ROBINSON, G. - ROBSON, P. - CHARLI, E. ROGERS, C. - SCALICI, G. - SCHUELE, H. - SHAFIEI, R. - SHEVCHUK, O. - SCHWARZ. K-U. - SQUANCE, M. - SWALLER, T. - THORTHON, J. - TRUCKSES, T.BOTNARI, V.- VIZIR, I. - WAGNER, M. - WARREN, R. - WEBSTER, R.- TOSHIHIKO, Y. -YOUELL, S. - XI, Q. - ZONG, J. - FLAVELL, R. 2017. Progress in upscaling Miscanthus biomass production for the European bio-economy with seed-based hybrids. In GCB Bioenergy, vol. 9, pp. 6-17. DOI:10.1111/gcbb.12357

COULETTE, Q. - COUNTY, A. - LAUSE, P. - RAMBAUD, C. - AMELINE, A. 2013. Colonization of the biomass energy crop miscanthus by the tree aphid species, Aphis fabae, Myzus persicae, and Rhopalosiphum padi. In Journal of Economic Entomology, vol. 106, pp. 683-689.

DAUBER, J. - CASS, S. - GABRIEL, D. - HARTE, K. ASTROME, S. - O'ROURKE, E. - STOUT, J.C. 2015. Yield-biodiversity trade-off in patchy field of Miscanthus $\times$ giganteus. In GCB Bioenergy, vol. 7, pp. 455-467. DOI: 10.1111/gcbb. 12167

GAUDER, M. - GRAEFF-HÖNNINGER, S. - LEWANDOWSKI, I. - CLAUPEIN, W. 2012. Long-term yield and performance of 15 different Miscanthus genotypes in southwest Germany. In Annals of Applied Biology, vol. 160, pp. 126-136. DOI:10.1111/j.1744-7348.2011.00526.x

GELETUKHA, G. - ZHELYEZNA, T.-TRYBOL, O. 2015. Prospects for growing and use of energy crops in Ukraine. In Journal Ecology of Enterprise, vol. 1, pp. 66-77 (in Russian).

GLOYNA, K. - THIEME, T. - ZELLNER, M. 2011. Miscanthus, a host for larvae of a European population of Diabrotica v. virgifera. In Journal of Applied Entomology, vol. 135, pp.780-785. DOI:10.1111/j.1439-0418.2010.01599.x

GOTTWALD, R. - ADAM, L. 1998. Ergebnisse zu entomologischen erhebungen und zur unkrautbekamprung bei Miscanthus und anderen C4-pflanzen. In Archives of Phytopathology and Plant Protection, vol. 31, pp. 377-386.

GRISHAM, M.P. - MAROON-LANGO, C.J. - HALE, A.L. 2012. First report of sorghum mosaic virus causing mosaic in Miscanthus sinensis. In Plant Disease, vol. 96, no.1, pp.150-151. DOI:10.1094/PDIS-07-11-0617

GUBIŠOVÁ, M. - GUBIŠ, J. - ŽOFAJOVÁ, A. 2016. Biomass production of gigantic grasses Arundo donax and Miscanthus $\times$ giganteus in the dependence on plant multiplication method. In Agriculture (Pol'nohospodárstvo), vol. 62, no. 2, pp. 43-51. DOI:10.1515/agri-2016-0005

HEATON, E.A. - DOHLEMAN, F.G. - LONG, S.P. 2008. Meeting US biofuel goals with less land: the potential of Miscanthus. In Global Change Biology, vol. 14, pp. 2000 2014. DOI:10.1111/j.1365-2486.2008.01662.x

HODKINSON, T.R. - CHASE, M.V. - RENVOIZE, S.A. 2002. Characterization of a genetic resource collection for Miscanthus (Saccharinae, Andropogoneae, Poaceae) using AFLP and ISSR PCR. In Annals of Botany, vol. 89, no. 5, pp. 627-636. DOI:10.1093/aob/mcf091

HUGGETT, D.A.J - LEATHER, S.R. - WALTERS, K.F.A. 1999. Suitability of biomass crop Miscanthus sinensis as a host for the aphids Rhopalosiphum padi (L.) and Rhopalosiphum miadis (F.) and its susceptibility to the plant luteovirus Barley yellow dwarf virus. In Agricultural and Forest Entomology, vol. 1, pp.143-149. 
HUREJ, M.J. - TWARDOWSKI, J. 2009. Phytophagous of energy crop Miscanthus $\times$ giganteus. In Progress in Plant Protection, vol. 49, pp. 1183-1186.

DAUBER, G. - JONES, M.B. - STOUT, J.C. 2012. The impact of biomass crop cultivation on temperate biodiversity. In GCB Bioenergy, vol. 2, pp. 289-309. DOI:10.1111/j.17571707.2010.01058.x

JUREKOVÁ, Z. - KOTRLA, M. - PAUKOVÁ, Ž. 2013. Life cycle of Miscanthus $\times$ giganteus (Greef et Deu) grown in Southwestern Slovakia conditions. In Acta regionalia et environmentalica, Nitra, Slovaca Universitas Agriculturae Nitriae, vol. 2, pp. 38-41. DOI: 10.2478/aree-2013-0008

KVAK, V.M. 2013. Impact of miscanthus rhizomes planting date and depth at the establishment in the field. In Zukrovi Buryaki, vol. 6, pp.15-17 (in Ukrainian).

LEWANDOWSKI, I. - SCURLOCK, J.M.O. - LINDVALL, E. - CHRISTOU, M. 2003. The development and current status of perennial rhizomatous grasses as energy crops in Europe and US. In Biomass and Bioenergy, vol. 25, no. 4, pp. 335-361. DOI: 10.1016/S0961-9534(03)00030-8

LEWINSOHN, T.M. - NOVOTNÝ, V. - BASSET, Y. 2005. Insects on plants: diversity of herbivore assemblages revisited. In Annual Review of Ecology Evolution, and Systematic, vol. 36, pp. 597-620.

NSANGANWIMANA, F. - WATERPLOT, C. - LOUVEL, B.- POURRUT, B. - DOUAY, F. 2016. Metal, nutrient and biomass accumulation during the growing cycle of Miscanthus established on metal-contaminated soils. In Journal of Plant nutrition and Soil Science, vol. 179, pp. 257-269. DOI:10.1002/jpln.201500163

OTEPKA, P. - HABÁN, M. - HABÁNOVÁ, M. 2011. Cultivation of fast-growing woody plant basket willow (Salix viminalis L.) and their bio remedial abilities while fertilized with wood ash. In Research Journal of Agricultural Science, vol. 43, no. 2, pp. 218-222.

PALLIPPARAMBIl, G.R. - CHA, G. - GRAY, M.E. 2014. A comparative life- table analysis of Sipha flava (Hemiptera: Aphididae) on two biofuel hosts: Miscanthus $\times$ giganteus and Saccharum spp. In Journal of Economic Entomology, vol. 107 , no. 3, pp. 1069-1075.

PIDLISNYUK, V. - STEFANOVSKA, T. - LEWIS, E. - ERICKSON, L. - DAVIS, L. 2014. Miscanthus as a productive crop for phytoremediation. In Critical Reviews in Plant Sciences, vol. 33, pp. 1-19. DOI:10.1080/07352689.2014 .847616

PIDLISNYUK, V. - STEFANOVSKA, T. 2016. Phytotechnology with biomass production for revitalization of the soils contaminated and damaged by military activities. Kyiev, Ukraine: NULES Publishing. 106 pp., ISBN 978-617-739614-6

PORVAZ, P. - TÓTH, Š. - MARCIN, A. 2012. Cultivation of Chinese silvergrass (Miscanthus sinensis Anderss.) on the East Slovak Lowland as a potential source of raw material for energy purposes. In Agriculture (Pol'nohospodárstvo), vol. 58 , no. 4 , pp. 146-153. DOI: 10.2478/v10207-0120016-5

PRASIFKA, J.R. - LOPEZ, M.D. - HELLMICH, R.L. - LEWIS, L.C. - DIVELY, G.P. 2007. Comparison of pitfall traps and litter bags for sampling ground-dwelling arthropods. In Journal of Applied Entomology, vol. 131, no. 2, pp.115120. DOI:10.1111/j.1439-0418.2006.01141.x

PRASIFKA, J.R. - BRADSHAW, J.D. - MEAGHER, R.L. NAGOSHI, R.N. - STEFFEY, K.L. - GRAY, M.E. 2009. Development and feeding of fall armyworm on Miscanthus $\times$ giganteus and switchgrass. In Journal of Economic Entomology, vol. 102, no. 6, pp. 2154-2159.
PRASIFKA, J.R. - BRADSHAW, J.D. - GRAY, M.E. 2012. Potential biomass reductions to Miscanthus $\times$ giganteus by stem-boring caterpillars. In Environmental Entomology, vol. 41 , no. 4 , pp. 865-871.

RICKLEFS, R.E. - SCHLUTER, D. (Ed.). 1994. Species Diversity in Ecological Communities: Historical and Geographical Perspectives. Chicago: University of Chicago Press, 414 pp. ISBN: 0-226-71823-9

ROCCA, M. - GRECO, N. 2011. Diversity of herbivorous communities in blueberry crops of different regions of $\mathrm{Ar}$ gentina. In Environmental Entomology, vol. 40, no. 2, pp. 247-259. DOI: 10.1603/EN10206

SEMERE, T. - SLATER, F.M. 2007. Invertebrate populations in miscanthus (Miscanthus $x$ giganteus) and reed canary-grass (Phalaris arundinacea) fields. In Biomass Bioenergy, vol. 31, no.1, pp. 30-39. DOI:10.1016/j.biombioe.2006.07.002

SHANNON, C.A. - 1948. Mathematical Theory of Communication. In Bell System Technical Journal, vol. 27, pp. 379-423.

SCHLUTER, D. - RICKLEFS, R.E. 1994. Species diversity: an introduction to the problem. In RICKLEFS, R.E SCHLUTER, D. (Ed.) Species diversity in ecological communities: historical and geographical perspectives. The University of Chicago Press, USA, $414 \mathrm{pp}$.

SPENCER, J.L. - RAGHU, S. 2009. Refuge or reservoir the potential impacts of the biofuel crop Miscanthus $\times$ giganteus on a major pest of maize. In PLoS ONE, vol. 4, no.12. DOI:10.1371/journal.pone.0008336:e8336

STANLEY, D.A. - STOUT, J.C. 2013. Quantifying the impacts of bioenergy crops on pollinating insect abundance and diversity: a field-scale evaluation reveals taxon-specific responses. In Applied Ecology, vol. 50, pp. 335-344. DOI: $10.1111 / 1365-2664.12060$

STEFANOVSKA, T. - LEWIS, E. - PIDLISNYUK, V. 2011. Evaluation a potential risk for agricultural landscape from second generation biofuel production in Ukraine: the role of pests. In Aspects of Applied Biology, vol. 109, pp.165-169. ISBN 0265-1491

STRAŠIL, Z. 2016. Evaluation of Miscanthus grown for energy use. In Research in Agricultural Engineering, vol. 62, pp. 92-97. DOI:10.17221/31/2014-RAE

THOMSON, L.J. - HOFFMANN, A.A. 2010. Pest management challenges for biofuel crop production. In Current Opinion in Environmental Sustainability, vol. 3, no. 1-2, pp. 95-99. DOI: 10.1016/j.cosust.2010.11.003

VAPROVA, K. - KNAPEK, J. 2010. Economic Assessment of Miscanthus Cultivation for energy purposes in the Czech Republic. In Journal of the Japan Institute of Energy, vol. 91, pp. 485-494.

WHITTAKER, R.J. - WILLIS, K.J. - FIELD, R. 2001. Scale and species richness: towards a general, hierarchical theory of species diversity. In Journal of Biogeography, vol. 28 , pp. 453-470. DOI:10.1046/j.1365-2699.2001.00563x

ZUB, H.W. - BRANCOURT-HULMEL, M. 2010. Agronomic and physiological performances of different species of Miscanthus, a major energy crop. A Review. In Agronomy for Sustainable Development, vol. 30, pp. 201-214. DOI: 10.1051/agro/2009034

Received: February 15, 2017 